\title{
Evaluation of expanded uncertainty at glass thermometer calibration
}

\author{
I. Zakharov, O. Botsiura, A. Brikman, O. Zakharov \\ Kharkiv National University of Radio Electronics, Nauky Ave., 14, 61166, Kharkiv, Ukraine \\ newzip@ukr.net
}

\section{Abstract}

A method for calibrating a glass thermometer is investigated and a procedure for measurement uncertainty evaluation based on the kurtosis method is developed. The correlation between the indication of the reference and calibrated thermometers at uncertainty evaluation is taken into account. The effectiveness of the reduction method applying in calculating the uncertainty of correlated measurements is demonstrated. Uncertainty budgets have been drawn up, which can be used as the basis for developing software tools to automate the uncertainty evaluation. A real example of the measurement uncertainty evaluation at glass thermometer calibration is considered. It is shown that taking into account the correlation between the measurement results of the calibrated and reference thermometers allows to reduce the values of the combined and expanded measurement uncertainty by almost 1.5 times. The coincidence of the results obtained by the proposed method and the Monte Carlo method is shown.

Keywords: glass thermometer; calibration; correlation; measurement uncertainty; kurtosis method; uncertainty budget.

\section{Introduction}

Glass thermometers are widespread in laboratory and industrial practice due to the high accuracy, cheapness, ease of use [1]. Their measurement range, depending on the thermometric fluid used (mercury, toluene, ethyl alcohol, kerosene, petroleum ether, pentane), extends from -200 to $+750{ }^{\circ} \mathrm{C}$.

Glass thermometers, like other measuring instruments, need periodic calibration. In this case, in accordance with the requirements of the standard ISO/ IEC 17025 [2], it is necessary to evaluate the measurement uncertainty. The main method for calibrating these thermometers is to compare them with a reference thermometer using a transfer device (thermostat). In the process of calibrating a thermometer, the difference $\Delta$ between the indications of the calibrated thermometer and the reference thermometer is estimated, thus determining the systematic error of the calibrated thermometer at the calibration point [3].

Since the measurements by both thermometers are carried out simultaneously under the same conditions, the instability of the temperature of the thermostat causes a statistical interrelation (correlation) between their indications, which must be taken into account when developing the procedure of measurement uncertainty evaluation.

\section{Analysis of literary data and problem statement}

Currently, the efforts of Working Group 1 (WG-1) of the Joint Committee for Guides in Metrology
(JCGM) are focused on revision the Guide to the Expression of Uncertainty in Measurement (GUM) [4]. The reason for the revision is the inconsistency of the uncertainty estimates obtained by the GUM method [5] and estimates obtained by the Monte Carlo Method (MCM) in accordance with Supplement 1 to the GUM [6]. Since [6] is based on the Bayesian approach to the measurement uncertainty evaluation, this approach should also be used in the revised Guide (NewGUM). In this case, it is necessary to consider the issues of taking into account correlation in the measurement uncertainty evaluation [7].

\section{The purpose and objectives of the study}

The article considers the procedure for measurement uncertainty evaluation based on the Bayesian approach [4], which implements the kurtosis method proposed by the authors [8]. To determine the reliability of the developed procedure, one should compare its results with the results obtained by the Monte Carlo method [9].

\section{Measurement Uncertainty Evaluation Algorithm}

1. Measurement model.

The error of indication $E_{\mathrm{x}}$ of the calibrated thermometer obtained from the relation:

$$
E_{\mathrm{X}}=\left(T_{\mathrm{c}}+\Delta_{\mathrm{c}}\right)-\left(T_{\mathrm{s}}+\Delta_{\mathrm{s}}\right)+\Delta_{\mathrm{T}},
$$


where $T_{\mathrm{c}}$ is the temperature indicated by the calibrated thermometer; $T_{\mathrm{s}}$ is the temperature indicated by the reference thermometer; $\Delta_{\mathrm{s}}$ is the correction due to calibration error of the reference thermometer; $\Delta_{\mathrm{c}}$ is the correction due to the finite resolution of the calibrated thermometer; $\Delta_{\mathrm{T}}$ is the correction due to the temperature unevenness inside the thermostat.

2. Input quantities evaluation of the equation (1).

Estimates $T_{\mathrm{c}}$ and $T_{\mathrm{s}}$ are obtained according to expressions:

$$
\begin{aligned}
& \bar{T}_{\mathrm{c}}=\frac{1}{n} \sum_{i=1}^{n} T_{\mathrm{ci}} ; \\
& \bar{T}_{\mathrm{s}}=\frac{1}{n} \sum_{i=1}^{n} T_{\mathrm{si}},
\end{aligned}
$$

where $T_{\mathrm{ci}}, T_{\mathrm{si}}$ are indications of calibrated and reference thermometers; $n$ is the number of indications.

All corrections in expression (1) are centered values, so their estimates are zero:

$$
\widehat{\Delta}_{\mathrm{c}}=0 ; \widehat{\Delta}_{\mathrm{s}}=0 ; \widehat{\Delta}_{\mathrm{T}}=0 .
$$

3. The estimate of the measurand $E_{\mathrm{X}}$ is obtained by substitution of input quantity estimates (2)-(4) in the equation (1):

$$
\widehat{E}_{\mathrm{x}}=\left(\bar{T}_{\mathrm{c}}+\widehat{\Delta}_{\mathrm{c}}\right)-\left(\bar{T}_{\mathrm{s}}+\widehat{\Delta}_{\mathrm{s}}\right)+\widehat{\Delta}_{\mathrm{T}}=\bar{T}_{\mathrm{c}}-\bar{T}_{\mathrm{s}} .
$$

A similar estimate of the measurand can also be obtained by the reduction method [10]:

$$
\bar{E}_{\mathrm{x}}=\frac{1}{n} \sum_{i=1}^{n}\left(T_{\mathrm{ci}}-T_{\mathrm{si}}\right)=\frac{1}{n} \sum_{i=1}^{n} \Delta_{\mathrm{i}}=\bar{\Delta} .
$$

4. Standard uncertainty evaluation of input quantities:

- standard uncertainty caused by the dispersion of calibrated thermometer indications:

$$
u\left(\bar{T}_{\mathrm{c}}\right)=\sqrt{\frac{n-1}{n-3}} \sqrt{\frac{1}{n(n-1)} \sum_{i=1}^{n}\left(T_{\mathrm{ci}}-\bar{T}_{\mathrm{c}}\right)^{2}} ;
$$

- standard uncertainty caused by the dispersion of the reference thermometer indications:

$$
u\left(\bar{T}_{\mathrm{s}}\right)=\sqrt{\frac{n-1}{n-3}} \sqrt{\frac{1}{n(n-1)} \sum_{i=1}^{n}\left(T_{\mathrm{si}}-\bar{T}_{\mathrm{s}}\right)^{2}} ;
$$

- standard uncertainty due to the finite resolution of the calibrated thermometer:

$$
u\left(\Delta_{\mathrm{c}}\right)=\frac{d}{2 \sqrt{3}}
$$

where $d$ is the resolution of the calibrated thermometer;

- standard uncertainty of the reference thermometer:

$$
u\left(\Delta_{\mathrm{s}}\right)=\frac{U_{\mathrm{s}}}{k_{\mathrm{s}}},
$$

where $U_{\mathrm{s}}$ and $k_{\mathrm{s}}$, respectively, the expanded uncertainty and coverage factor taken from the reference thermometer calibration certificate;

- standard uncertainty associated with the temperature unevenness in the thermostat:

$$
u\left(\Delta_{\mathrm{T}}\right)=\frac{\theta_{\mathrm{T}}}{\sqrt{3}},
$$

where $\theta_{\mathrm{T}}$ is the limit of temperature unevenness in the thermostat.

7. Determination of pairwise correlation of input quantities

The change in temperature in the thermostat leads to a correlation between the indications of the reference and the calibrated thermometers. Estimate of coefficient of correlation is made by the formula:

$$
r_{\mathrm{c}, \mathrm{s}}=\frac{\sum_{i=1}^{n}\left(T_{\mathrm{ci}}-\bar{T}_{\mathrm{c}}\right)\left(T_{\mathrm{si}}-\bar{T}_{s}\right)}{\sqrt{\sum_{i=1}^{n}\left(T_{\mathrm{ci}}-\bar{T}_{\mathrm{c}}\right)^{2}} \sqrt{\sum_{i=1}^{n}\left(T_{\mathrm{si}}-\bar{T}_{\mathrm{s}}\right)^{2}}} .
$$

With a small number of measurements, it is necessary to check the significance of the coefficient of correlation according to the Student's criterion:

$$
\frac{\left|r_{\mathrm{c}, \mathrm{s}}\right|}{\sqrt{1-r_{\mathrm{c}, \mathrm{s}}^{2}}} \sqrt{n-2} \geq t_{0,95 ;(n-2)},
$$

where $t_{0,95 ;(n-2)}$ is the Student's coefficient for the probability of 0.95 and the number of degrees of freedom $n-2$. If inequality (13) is performed, the correlation between the $T_{\mathrm{c}}$ and $T_{\mathrm{s}}$ is considered to be established and should be taken into account at measurand uncertainty evaluation.

The standard uncertainty of the measurand is calculated according to the formula:

$$
u\left(E_{\mathrm{x}}\right)=\sqrt{\left[u^{2}\left(\bar{T}_{\mathrm{c}}\right)-2 r_{\mathrm{c}, \mathrm{s}} u\left(\bar{T}_{\mathrm{c}}\right) u\left(\bar{T}_{\mathrm{s}}\right)+u^{2}\left(\bar{T}_{\mathrm{s}}\right)\right]+u^{2}\left(\Delta_{\mathrm{c}}\right)+u^{2}\left(\Delta_{\mathrm{s}}\right)+u^{2}\left(\Delta_{\mathrm{T}}\right)} .
$$


If there is a correlation between the reference and calibrated thermometer indications, the reduction method and a simpler expression to calculate $u\left(E_{\mathrm{X}}\right)$ can be used:

$u\left(E_{\mathrm{X}}\right)=\sqrt{u^{2}(\bar{\Delta})+u^{2}\left(\Delta_{\mathrm{c}}\right)+u^{2}\left(\Delta_{\mathrm{s}}\right)+u^{2}\left(\Delta_{\mathrm{T}}\right)}$,

where $u(\bar{\Delta})$ is standard uncertainty of observed dispersion of the varying indications of thermometers will be determined like that:

$$
\begin{aligned}
& u(\bar{\Delta})=\sqrt{\frac{n-1}{n-3}} \sqrt{\frac{1}{n(n-1)} \sum_{i=1}^{n}\left(\Delta_{\mathrm{i}}-\bar{\Delta}\right)^{2}} . \quad \text { (16) } \quad \begin{array}{l}
\text { and } \eta \text { is the kurtosis of the distribution of the } \\
\text { measurand, determined as: }
\end{array} \\
& \eta=\frac{\eta\left(\bar{T}_{\mathrm{c}}\right)\left[u^{2}\left(\bar{T}_{\mathrm{c}}\right)-2 r_{\mathrm{c}, \mathrm{s}} u\left(\bar{T}_{\mathrm{c}}\right) u\left(\bar{T}_{\mathrm{s}}\right)+u^{2}\left(\bar{T}_{\mathrm{s}}\right)\right]^{2}+\eta\left(\Delta_{\mathrm{c}}\right) u^{4}\left(\Delta_{\mathrm{c}}\right)+\eta\left(\Delta_{\mathrm{s}}\right) u^{4}\left(\Delta_{\mathrm{s}}\right)+\eta\left(\Delta_{\mathrm{T}}\right) u^{4}\left(\Delta_{\mathrm{T}}\right)}{u^{4}\left(E_{\mathrm{x}}\right)},
\end{aligned}
$$

or when evaluating by the reduction method:

$$
\eta=\frac{\eta(\bar{\Delta}) u^{4}(\bar{\Delta})+\eta\left(\Delta_{\mathrm{c}}\right) u^{4}\left(\Delta_{\mathrm{c}}\right)+\eta\left(\Delta_{\mathrm{s}}\right) u^{4}\left(\Delta_{\mathrm{s}}\right)+\eta\left(\Delta_{\mathrm{T}}\right) u^{4}\left(\Delta_{\mathrm{T}}\right)}{u^{4}\left(E_{\mathrm{x}}\right)},
$$

where the kurtosis values of input quantities are taken from Table 1 in accordance with their distribution laws. With this $\eta(\bar{\Delta})=\eta\left(\bar{T}_{\mathrm{c}}\right)=\eta\left(\bar{T}_{\mathrm{s}}\right)=6 /(n-5)$.

Table 1

Kurtosis values for different input distribution laws

\begin{tabular}{|c|c|c|c|c|c|}
\hline Distribution law & Arcsine & Uniform & Triangular & Normal & Student's with the number of degrees of freedom $v$ \\
\hline Kurtosis & -1.5 & -1.2 & -0.6 & 0 & $6 /(v-4)$ \\
\hline
\end{tabular}

10. Uncertainty budget

All above obtained information on input quantities and measurand is summarized in Table 2, which is an uncertainty budget.

Table 2

Uncertainty budget of measurement at thermometer calibration

\begin{tabular}{|c|c|c|c|c|c|}
\hline Input quantities & $\begin{array}{c}\text { The values of } \\
\text { input quantities }\end{array}$ & $\begin{array}{c}\text { Standard } \\
\text { uncertainty of input } \\
\text { quantities }\end{array}$ & $\begin{array}{c}\text { Kurtosis } \\
\text { of input } \\
\text { quantities }\end{array}$ & $\begin{array}{c}\text { Sensitivity } \\
\text { coefficients }\end{array}$ & $\begin{array}{c}\text { Uncertainty } \\
\text { contribution }\end{array}$ \\
\hline$T_{\mathrm{c}}$ & $\bar{T}_{\mathrm{c}}$ & $u\left(\bar{T}_{\mathrm{c}}\right)$ & $\eta\left(\bar{T}_{\mathrm{c}}\right)$ & 1 & $u\left(\bar{T}_{\mathrm{c}}\right)$ \\
\hline$\Delta_{\mathrm{c}}$ & 0 & $u\left(\widehat{\Delta}_{\mathrm{c}}\right)$ & $\eta\left(\Delta_{\mathrm{c}}\right)$ & 1 & $u\left(\widehat{\Delta}_{\mathrm{c}}\right)$ \\
\hline$T_{\mathrm{s}}$ & $\bar{T}_{\mathrm{s}}$ & $u\left(\bar{T}_{\mathrm{s}}\right)$ & $\eta\left(\bar{T}_{\mathrm{s}}\right)$ & -1 & $-u\left(\bar{T}_{\mathrm{s}}\right)$ \\
\hline$\Delta_{\mathrm{s}}$ & 0 & $u\left(\widehat{\Delta}_{\mathrm{s}}\right)$ & $\eta\left(\Delta_{\mathrm{s}}\right)$ & -1 & $-u\left(\bar{\Delta}_{\mathrm{s}}\right)$ \\
\hline$\Delta_{\mathrm{T}}$ & 0 & $u\left(\widehat{\Delta}_{\mathrm{T}}\right)$ & $\eta\left(\Delta_{\mathrm{T}}\right)$ & 1 & $u\left(\widehat{\Delta}_{\mathrm{T}}\right)$ \\
\hline Measurand & $\begin{array}{c}\text { The value of the } \\
\text { measurand }\end{array}$ & $\begin{array}{c}\text { Combined } \\
\text { standard uncertainty }\end{array}$ & $\begin{array}{c}\text { Kurtosis of } \\
\text { measurand }\end{array}$ & $\begin{array}{c}\text { Coverage } \\
\text { factor }\end{array}$ & $\begin{array}{c}\text { Expanded } \\
\text { uncertainty }\end{array}$ \\
\hline$E_{\mathrm{x}}$ & $\widehat{E}_{\mathrm{x}}$ & $u\left(E_{\mathrm{x}}\right)$ & $\eta$ & $k$ & $U$ \\
\hline
\end{tabular}

The uncertainty budget is convenient to use as a basis for building a software tool to automate the process of measurement uncertainty evaluation. The uncertainty budget with applying the reduction method is shown in Table 3. 
Uncertainty budget of measurement at thermometer calibration (reduction method)

\begin{tabular}{|c|c|c|c|c|c|}
\hline $\begin{array}{c}\text { Input } \\
\text { quantities }\end{array}$ & $\begin{array}{c}\text { The values of } \\
\text { input quantities }\end{array}$ & $\begin{array}{c}\text { Standard uncertainty } \\
\text { of input quantities }\end{array}$ & $\begin{array}{c}\text { Kurtosis of } \\
\text { input quantities }\end{array}$ & $\begin{array}{c}\text { Sensitivity } \\
\text { coefficients }\end{array}$ & $\begin{array}{c}\text { Uncertainty } \\
\text { contribution }\end{array}$ \\
\hline$\Delta$ & $\bar{\Delta}$ & $u(\bar{\Delta})$ & $\eta(\bar{\Delta})$ & 1 & $u(\bar{\Delta})$ \\
\hline$\Delta_{\mathrm{c}}$ & 0 & $u\left(\widehat{\Delta}_{\mathrm{c}}\right)$ & $\eta\left(\Delta_{\mathrm{c}}\right)$ & 1 & $u\left(\widehat{\Delta}_{\mathrm{c}}\right)$ \\
\hline$\Delta_{\mathrm{s}}$ & 0 & $u\left(\widehat{\Delta}_{\mathrm{s}}\right)$ & $\eta\left(\Delta_{\mathrm{s}}\right)$ & -1 & $-u\left(\widehat{\Delta}_{\mathrm{s}}\right)$ \\
\hline$\Delta_{\mathrm{T}}$ & 0 & $u\left(\widehat{\Delta}_{\mathrm{T}}\right)$ & $\eta\left(\Delta_{\mathrm{T}}\right)$ & 1 & $u\left(\widehat{\Delta}_{\mathrm{T}}\right)$ \\
\hline Measurand & $\begin{array}{c}\text { The value of the } \\
\text { measurand }\end{array}$ & $\begin{array}{c}\text { Combined } \\
\text { standard uncertainty }\end{array}$ & $\begin{array}{c}\text { Kurtosis of } \\
\text { measurand }\end{array}$ & Coverage factor & $\begin{array}{c}\text { Expanded } \\
\text { uncertainty }\end{array}$ \\
\hline$E_{\mathrm{x}}$ & $\hat{E}_{\mathrm{x}}$ & $u\left(E_{\mathrm{x}}\right)$ & $\eta$ & $u\left(\widehat{\Delta}_{\mathrm{T}}\right)$ & $U\left(E_{\mathrm{x}}\right)$ \\
\hline
\end{tabular}

\section{An example of measurement uncertainty evaluation}

Indications of calibrated and reference glass thermometers are shown in Table 4.

Table 4

Calibrated $T_{\text {ci }}$ and reference $T_{\mathrm{si}}$ thermometer indications

\begin{tabular}{|c|c|c|c|c|c|c|}
\hline$I$ & 1 & 2 & 3 & 4 & 5 & 6 \\
\hline$T_{\mathrm{ci},}{ }^{\circ} \mathrm{C}$ & 9.97 & 9.95 & 9.94 & 9.95 & 9.96 & 9.97 \\
\hline$T_{\mathrm{si}},{ }^{\circ} \mathrm{C}$ & 9.98 & 9.97 & 9.96 & 9.97 & 9.98 & 9.98 \\
\hline$\Delta_{\mathrm{i}},{ }^{\circ} \mathrm{C}$ & -0.01 & -0.02 & -0.02 & -0.02 & -0.02 & -0.01 \\
\hline
\end{tabular}

The resolution $d$ of calibrated thermometer is $0.1{ }^{\circ} \mathrm{C}$. Expanded uncertainty $U_{\mathrm{s}}=0.05{ }^{\circ} \mathrm{C}$ and coverage factor $k_{\mathrm{s}}=2$ are taken from the certificate of calibration of the reference thermometer. The limit of temperature unevenness $\theta_{\mathrm{T}}=0.004{ }^{\circ} \mathrm{C}$ is taken from the passport of the thermostat. The uncertainty budget for these data is listed in Table 5.

The uncertainty budget for the reduction method is presented in Table 6. The results of the measurement uncertainty evaluation for this example, obtained by the Monte Carlo method, are presented in Table 7 and completely coincide with the results of Tables 5 and 6 .

Table 5

Uncertainty budget when calibrating the thermometer at point $10{ }^{\circ} \mathrm{C}$

\begin{tabular}{|c|c|c|c|c|c|}
\hline $\begin{array}{c}\text { Input } \\
\text { quantities }\end{array}$ & $\begin{array}{c}\text { The values of } \\
\text { input quantities }\end{array}$ & $\begin{array}{c}\text { Standard uncertainty } \\
\text { of input quantities }\end{array}$ & $\begin{array}{c}\text { Kurtosis of } \\
\text { input quantities }\end{array}$ & $\begin{array}{c}\text { Sensitivity } \\
\text { coefficients }\end{array}$ & $\begin{array}{c}\text { Uncertainty } \\
\text { contribution }\end{array}$ \\
\hline$T_{\mathrm{c}}$ & 9.956667 & 0.006383 & 6 & 1 & 0.006383 \\
\hline$\Delta_{\mathrm{c}}$ & 0 & 0.002887 & -1.2 & 1 & 0.002887 \\
\hline$T_{\mathrm{s}}$ & 9.973333 & 0.004303 & 6 & -1 & -0.0043 \\
\hline$\Delta_{\mathrm{s}}$ & 0 & 0.0025 & 0 & -1 & -0.0025 \\
\hline$\Delta_{\mathrm{T}}$ & 0 & 0.002309 & -1.2 & 1 & 0.002309 \\
\hline Measurand & $\begin{array}{c}\text { The value of the } \\
\text { measurand }\end{array}$ & $\begin{array}{c}\text { Combined } \\
\text { standard uncertainty }\end{array}$ & $\begin{array}{c}\text { Kurtosis of } \\
\text { measurand }\end{array}$ & Coverage factor & $\begin{array}{c}\text { Expanded } \\
\text { uncertainty }\end{array}$ \\
\hline$E_{\mathrm{X}}$ & -0.01667 & 0.005227 & 0.283619 & 1.97597 & 0.010329 \\
\hline
\end{tabular}

Uncertainty budget when calibrating the thermometer at point $10{ }^{\circ} \mathrm{C}$ (reduction method)

\begin{tabular}{|c|c|c|c|c|c|}
\hline $\begin{array}{c}\text { Input } \\
\text { quantities }\end{array}$ & $\begin{array}{c}\text { The values of } \\
\text { input quantities }\end{array}$ & $\begin{array}{c}\text { Standard uncertainty } \\
\text { of input quantities }\end{array}$ & $\begin{array}{c}\text { Kurtosis of } \\
\text { input quantities }\end{array}$ & $\begin{array}{c}\text { Sensitivity } \\
\text { coefficients }\end{array}$ & $\begin{array}{c}\text { Uncertainty } \\
\text { contribution }\end{array}$ \\
\hline$\Delta$ & -0.0167 & 0.002722 & 6 & 1 & 0.002722 \\
\hline$\Delta_{\mathrm{c}}$ & 0 & 0.002887 & -1.2 & 1 & 0.002887 \\
\hline$\Delta_{\mathrm{s}}$ & 0 & 0.0025 & 0 & -1 & -0.0025 \\
\hline$\Delta_{\mathrm{T}}$ & 0 & 0.002309 & -1.2 & 1 & 0.002309 \\
\hline
\end{tabular}




\begin{tabular}{|c|c|c|c|c|c|}
\hline Measurand & $\begin{array}{c}\text { The value of the } \\
\text { measurand }\end{array}$ & $\begin{array}{c}\text { Combined } \\
\text { standard uncertainty }\end{array}$ & $\begin{array}{c}\text { Kurtosis of } \\
\text { measurand }\end{array}$ & Coverage factor & $\begin{array}{c}\text { Expanded } \\
\text { uncertainty }\end{array}$ \\
\hline$E_{\mathrm{X}}$ & -0.01667 & 0.005227 & 0.283619 & 1.976 & 0.01033 \\
\hline
\end{tabular}

Table 7

Monte Carlo measurement uncertainty evaluation results

\begin{tabular}{|c|c|c|c|c|}
\hline Measurand & The value of the measurand & $\begin{array}{c}\text { Combined standard } \\
\text { uncertainty }\end{array}$ & Coverage factor & Expanded uncertainty \\
\hline$E_{\mathrm{X}}$ & -0.01667 & 0.005227 & 1.974 & 0.01033 \\
\hline
\end{tabular}

\section{Conclusions}

1. The procedure of the measurement uncertainty evaluation at glass thermometer calibration, based on the Bayesian approach and the kurtosis method, is described.

2. Applying the reduction method to process correlated measurements makes it easier to calculate the measurement uncertainty.
3. The procedure is illustrated by a specific example, the results of which showed a complete agreement with the results of the calculation by the Monte Carlo method.

4. Taking into account the correlation between the measurement results of calibrated and reference thermometers allows to reduce the values of combined and expanded measurement uncertainties by almost 1.5 times.

\title{
Оцінювання розширеної невизначеності при калібруванні скляного термометра
}

\author{
І.П. Захаров, О.А. Боцюра, А.І. Брікман, О. О. Захаров \\ Харківський національний університет радіоелектроніки, пр. Науки, 14, 61166, Харків, Україна \\ newzip@ukr.net
}

\section{Анотація}

Досліджено методику калібрування скляного термометра методом звірення з еталонним термометром за допомогою приладу порівняння (термостата). Згідно з вимогами стандарту ISO/IEC 17025 розроблено процедуру оцінювання невизначеності вимірювань. В основу цієї процедури покладено байєсівський підхід та розроблений авторами метод ексцесів. Застосування цих прийомів дозволяє наблизити оцінки невизначеності вимірювань, отримані запропонованим методом до оцінок невизначеності вимірювань, отриманих методом Монте-Карло відповідно до Додатку 1 до Настанови з подання невизначеності вимірювання. Під час обчислення сумарної стандартної невизначеності вимірювань проводиться облік кореляції між показами термометра, що калібрується, та еталонного термометра. Наявність кореляції викликана одночасними вимірюваннями в одних умовах температури обома термометрами та нестабільністю температури термостата. Продемонстровано ефективність застосування методу редукції при розрахунку невизначеності корельованих вимірювань. Складено бюджети невизначеності, які можна використовувати як основу для розробки програмного засобу з метою автоматизації оцінювання невизначеності вимірювань. Отримано формули для обчислення ексцесу вимірюваної величини з урахуванням кореляції між вхідними величинами при використанні загальноприйнятого методу обчислення невизначеності та методу редукції. Розглянуто реальний приклад оцінки невизначеності вимірювань під час калібрування скляного термометра. Показано, що облік кореляції між результатами вимірювань термометра, що калібрується, і еталонного термометра дозволяє знизити значення сумарної та розширеної похибок вимірювань майже в 1,5 раза. Продемонстровано збіг результатів, отриманих запропонованим методом і методом Монте-Карло.

Ключові слова: термометр скляний; калібрування; кореляція; невизначеність вимірювань; байєсівський підхід; метод ексцесів; бюджет невизначеності. 


\title{
Оценивание расширенной неопределенности при калибровке стеклянного термометра
}

\author{
И.П. Захаров, О.А. Боцюра, А.И. Брикман, А.А. Захаров \\ Харьковский национальный университет радиоэлектроники, пр. Науки, 14, 61166, Харьков, Украина \\ newzip@ukr.net
}

\section{Аннотация}

Исследована методика калибровки стеклянного термометра и разработана процедура оценивания неопределенности измерений на основе метода эксцессов. При оценивании неопределенности производится учет корреляции между показаниями эталонного и калибруемого термометров. Продемонстрирована эффективность применения метода редукции при расчете неопределенности коррелированных измерений. Составлены бюджеты неопределенности, которые можно использовать в качестве основы для разработки программного средства с целью автоматизации оценивания неопределенности. Рассмотрен реальный пример оценки неопределенности измерений при калибровке стеклянного термометра. Показано, что учет корреляции между результатами измерений калибруемого и эталонного термометров позволяет снизить значения суммарной и расширенной погрешностей измерений почти в 1,5 раза. Показано совпадение результатов, полученных предлагаемым методом и методом Монте-Карло.

Ключевые слова: термометр стеклянный; калибровка; корреляция; неопределенность измерений; метод эксцессов; бюджет неопределенности.

\section{References}

1. Preobrazhensky V.P. Teplotehnicheskie izmereniya i pribory [Thermotechnical measurements and devices]. Moscow, Energiya, 1978. 704 p. (in Russian).

2. ISO/IEC 17025:2017. General requirements for the competence of testing and calibration laboratories, 2017. $38 \mathrm{p}$.

3. Zakharov I.P., Vodotyka S.V., Shevchenko E. N. Methods, models, and budgets for estimation of measurement uncertainty during calibration. Measurement Techniques, July, 2011, vol. 54, no. 4, pp. 387-399.

4. Bich W., Cox M. and Michotte C. Towards a new GUM - an update. Metrologia, 2016, 53(5): S149-S159. doi: 10.1088/0026-1394/53/5/S149

5. JCGM 100:2008. Evaluation of measurement data - Guide to the expression of uncertainty in measurement. JCGM, 2008. $134 \mathrm{p}$.

6. JCGM 101:2008. Evaluation of measurement data - Supplement 1 to the "Guide to the expres- sion of uncertainty in measurement" - Propagation of distributions using a Monte Carlo method. JCGM, 2008. 90 p.

7. Zakharov I.P. Estimating measurement uncertainty on the basis of observed and logical correlation. Measurement Techniques, 2007, vol. 50, no. 8, pp. 808-816.

8. Zakharov I. P., Botsyura O.A. Calculation of Expanded Uncertainty in Measurements Using the Kurtosis Method when Implementing a Bayesian Approach. Measurement Techniques, 2019, vol. 62(4), pp. 327-331. doi: 10.1007/s11018-01901625-x

9. Zakharov I. P., Vodotyka S. V. Application of Monte Carlo simulation for the evaluation of measurements uncertainty. Metrology and Measurement Systems, 2008, vol. 15, no. 1, pp. 117-123.

10. Rabinovich S. G. Evaluating Measurement Accuracy: A Practical Approach. 2nd ed. Springer, 2013. $313 \mathrm{p}$. 